\title{
Prevalence of Blood Groups at the Blood Transfusion Center at the Military Hospital Avicenna of Marrakech
}

\author{
Amaddah Radia ${ }^{1, *}$, Beddou Ghita ${ }^{1}$, Skali Hajar ${ }^{1}$, Yahyaoui Hicham ${ }^{1,2}$, Ait Ameur Mustapha ${ }^{1,2}$, \\ Chakour Mohamed ${ }^{1,2}$ \\ ${ }^{1}$ Hematology Laboratory Military Hospital Avicenna of Marrakech, Marrakech, Morocco \\ ${ }^{2}$ Blood Transfusion Center Military Hospital Avicenna of Marrakech, Marrakech, Morocco
}

Email address:

Radiat.sa@gmail.com (A. Radia)

${ }^{*}$ Corresponding author

\section{To cite this article:}

Amaddah Radia, Beddou Ghita, Skali Hajar, Yahyaoui Hicham, Ait Ameur Mustapha, Chakour Mohamed. Prevalence of Blood Groups at the Blood Transfusion Center at the Military Hospital Avicenna of Marrakech. American Journal of Laboratory Medicine.

Vol. 4, No. 6, 2019, pp. 101-104. doi: 10.11648/j.ajlm.20190406.13

Received: October 15, 2019; Accepted: November 4, 2019; Published: November 18, 2019

\begin{abstract}
The $\mathrm{ABO}$ and RHD systems represent the most immunogenic systems and the most sought after in blood transfusion. The objective of this work was to present new statistics of phenotypic prevalence of ABO and RHD systems in Morocco using a new sample. Our study was a retrospective, descriptive and epidemiological one carried out at the Blood Transfusion Center at the Avicenne Military Hospital in Marrakech on a sample of 10,000 donors collected between the year 2009 and the year 2017. The study of the expression Erythrocyte blood group antigens by the serological phenotyping technique was based on haemagglutination. Double determination was necessary to avoid the risk of grouping errors. This technique was simple and inexpensive, and today remains a gold standard for immunohematology. At the end of this study, the frequency of the antigens of the red blood cell systems $\mathrm{ABO}$ and RHD was as follows: $\mathrm{ABO}$ system: A (32.7\%), B (16.33\%), AB (5.26\%), O (45.71\%). RHD system: RHD positive (92.29\%), RHD negative (7.71\%). Our results were compared to other previous Moroccan and other foreign countries studies; this allowed us to locate hemotypologically the transfusion center of the Avicenne military hospital of Marrakech in the world. At the end of this study, we have concluded that our results were consistent with previous studies in Morocco. These results were identical to those found in the Mediterranean countries and showed that Morocco was in an intermediate position between the countries of Europe and those of Black Africa.
\end{abstract}

Keywords: Prevalence, Blood Transfusion, ABO, RHD

\section{Introduction}

A blood group is a set of elements that makes it possible to characterize a human being, to individualize him/her or to group him/her within a population according to common characteristics. A blood group is defined as a set of allotypic, genetically induced, determined, and independent antigens expressed on the surface of one or more types of blood elements. Currently there are more than 700 antigens and several blood group systems evaluated at about 339 and distributed in 36 systems including $\mathrm{ABO}$ and $\mathrm{RH}$ which are erythrocyte systems that are the subject of our study [1]. Knowledge of the molecular basis of polymorphism erythrocyte blood groups have led to new developments in immuno-hematology.

The identification of the blood group $\mathrm{ABO}$ was a major step in the control of transfusion therapy. The ABO blood group system is the main type of blood groups classified into four phenotypes (A, B, O and $\mathrm{AB}$ ) depending on the presence or absence of specific antigens and antibodies on the red cell membrane or in the plasma [2]. The RH system is the second system of erythrocyte blood groups encountered in the human species. There are several protein antigens in this system, the main one is the D antigen, which is incriminated in immune reactions [3].

The objective of our study was to draw up the phenotypic 
profile of blood groups ABO and RHD within a representative military population of the city of Marrakech and its regions recruited over a period of 8 years for whom a biological qualification (among others immunological) was performed according to the standards of transfusion safety in force in our country.

\section{Patients and Methods}

\subsection{Population}

Our Study targeted a military population of Marrakech and its regions (Bengrir, Kasbah Tadla, Ouarzazate...), whose ages range between 18 and 55 years. They were collected according to scheduled collections for intra-hospital internal use ( 2 to 3 collections per month), which was equivalent to 120-150 donors per month.

The study took 8 years, from October 2009 to October 2017.

\subsection{Methodologies}

The samples were taken at our blood transfusion center at the HMA in Marrakech after a rigorous interrogation eliminating the counter indications of blood donation. The search for antigens on the red cell surface by the BethVincent test and natural antibodies at the plasma level, respectively, by the Simonin-Michon test, both techniques were carried out by two different technicians and were validated by witnesses. To establish an ABO blood group, both tests were mandatory and had to be concordant. The Rh system (or RHD) determines, according to the presence or absence of the D antigen on the red blood cells. It consists of looking for the Ag D (RH1) by direct agglutination technique between the $\mathrm{D}$ antigen focused on the red blood cells to be tested and the anti-D test serum.

\section{Results}

\subsection{Prevalence of the ABO System}

In our study blood group $\mathrm{O}$ held most of the phenotypes of the entire population studied (almost half) with a prevalence of $45.71 \%$ (4571 donors). The second position was occupied by the blood group with a prevalence of $32.7 \%$ (3270 donors). 1633 donors were phenotype B or $16.33 \%$. The latter came in 3rd position. And the $\mathrm{AB}$ group was the least expressed phenotype in our series with a prevalence of $5.26 \%$ (526 donors).

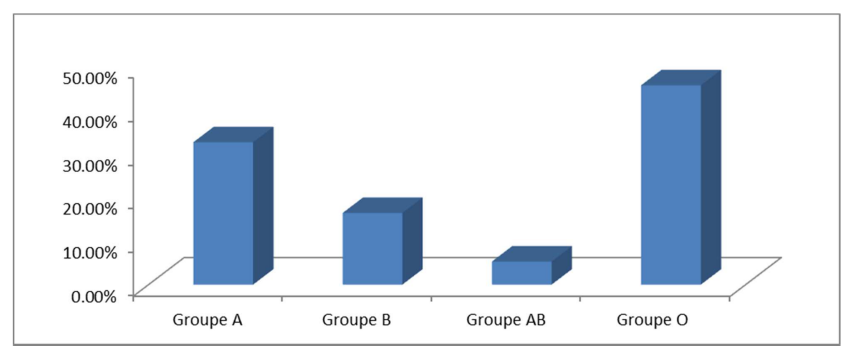

Figure 1. Prevalence of ABO blood groups in our study population.

\subsection{Prevalence of the RHD System}

In our series, RHD positive subjects were predominant with a percentage of $92.29 \%$, while RHD negative subjects were only $771(7.71 \%)$ of the study population.

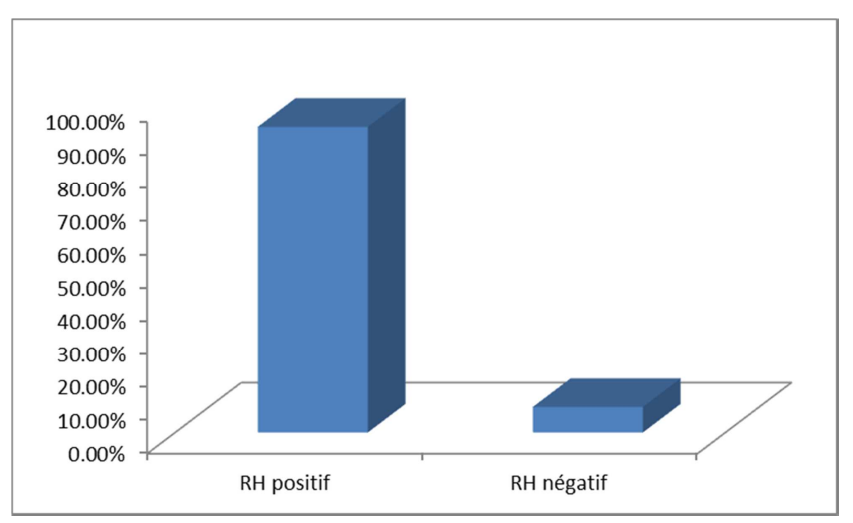

Figure 2. Prevalence of D antigen in our study population.

\subsection{Prevalence of the RHD System Combined with the ABO System}

Blood group $\mathrm{O} \mathrm{RH}+$ was the dominant group with a phenotypic frequency of $42.15 \%$ (4215 donors), followed by the blood group A RH + In our series, 3000 donors (30\%), the phenotype B RHD + took the 3rd position with 1543 donors either (15.43\%) after blood group $\mathrm{O}$ and $\mathrm{A}, 471$ donors were of the $\mathrm{AB}$ RHD + phenotype either (4.71\%). Concerning the negative RHD system combined with the ABO system, our series showed that among the 10,000 donors 357 were of the phenotype $\mathrm{O} \mathrm{RH}$ - with a prevalence of $3,57 \%, 270$ donors were of the group A RH- is $(2,70 \%)$ of the study population, followed by the blood group B RHwas found in 90 donors or $(0.9 \%)$, and lastly our survey had shown that just 54 donors were from group $\mathrm{AB}$ RH- with a prevalence of $0,54 \%$.

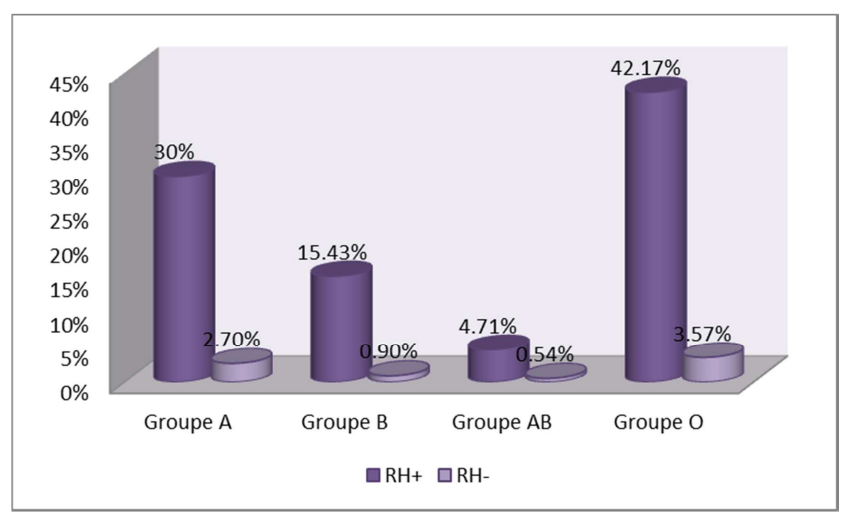

Figure 3. Prevalence of the RHD phenotype associated with the $A B O$ system.

\section{Discussion}

The two groups $\mathrm{O}$ and $\mathrm{A}$ had the highest prevalences while the $\mathrm{AB}$ group was present with a lower prevalence.

At national scale, concerning the blood group $\mathrm{O}$ in our 
series the prevalence was $45.71 \%$, a value close to that found in the study conducted by Khaloufi [4] in Meknes in 2016, Eddoum. K [5] made in Rabat, and that of Benhadi [6] with 219,287 donors from different regions of Morocco. Higher than that found in Erfoud during the Mechali. D investigation [7], but this survey had weak sample. The prevalence of the lowest blood group A was found in the Mechali. D study [7] in the Tinghir region $25 \%$. The study by Bennaka. L [6] showed a prevalence of $33.89 \%$, a value higher than that found in our study $32.7 \%$. In the El Akermi. I series [8], 32.69\% of the donors were blood group A, a value very similar to that found in our study. The study of Khaloufi [4], and that of Eddoum [5] found successively $15.92 \%$ and $16.25 \%$ of donors of the blood group B, value close to that found in our study $(16.33 \%)$.

Our study confirmed the results of those carried out previously at the level of the various Moroccan hospitals by demonstrating almost the same phenotypic frequencies A, B, $\mathrm{AB}$ and $\mathrm{O}$ within the population coming from the different regions of Morocco. At the end of our study we concluded that the groups of the $\mathrm{ABO}$ system predominated in descending order of group $\mathrm{O}$, group $\mathrm{A}$, group $\mathrm{B}$ and group AB.

At the international scale, the prevalences found in our study were similar to those of the Mediterranean rim showed the study done by Said et al [9] in Tunisia and Bennaka. 1 [10] in southern Italy, for the blood group $O$ the prevalence was lower than that of sub-Saharan Africa [11] and higher than that recorded in Europe as evidenced by the German [12] and French [13] study; in contrast to the blood group A, European studies showed higher values; $44.4 \%, 43.26 \%$ and 40.82\% [12-14] (Table 1).

Compared with Asian countries (northern India), Morocco showed higher frequencies, especially blood groups $\mathrm{A}$ and $\mathrm{O}$ (Table 1).

We concluded that the prevalence of ABO phenotypes in Morocco was intermediate between that of sub-Saharan Africa and that of Europe.

Table 1. Prevalence of ABO phenotypes at the international level.

\begin{tabular}{|c|c|c|c|c|c|}
\hline authors & countries & O\% & $\mathbf{A} \%$ & B\% & $\mathbf{A B} \%$ \\
\hline Deba. T [15] & Algeria & 50.4 & 29.3 & 13.2 & 6.9 \\
\hline Said et al [9] & Tunisia & 46.18 & 30.94 & 17.83 & 5.00 \\
\hline Bukasa et al [11] & Congo & 60.50 & 21.60 & 15.40 & 2.50 \\
\hline DULAT et al [16] & Ivory Coast & 48.10 & 23.7 & 23.6 & 4.6 \\
\hline Alia et al [11] & Iraq & 49.90 & 28.7 & 13.8 & 7.6 \\
\hline Parul et al [18] & North India & 28.7 & 28.7 & 32.07 & 10.53 \\
\hline Adrián et al [19] & Mexico & 61.82 & 27.44 & 8.93 & 1.81 \\
\hline Willy. A [13] & Germany & 41.21 & 43.26 & 10.71 & 4.82 \\
\hline Tlamçani. Z [20] & Australia & 49.00 & 38.00 & 10.00 & 3.00 \\
\hline Irem et al [12] & Turkey & 34.72 & 40.82 & 17.98 & 6.48 \\
\hline Bennaka. L [10] & Thaïland & 42.60 & 20.20 & 30.80 & 6.40 \\
\hline Loua et al [21] & Guinea & 48.88 & 22.54 & 23.86 & 4.72 \\
\hline Traoré. O [22] & Mali & 45.7 & 24 & 24.5 & 5.8 \\
\hline Ivanov et al [23] & Ukraine & 34.04 & 37.7 & 19.3 & 8.96 \\
\hline Our study & Morocco & 45.71 & 32.7 & 16.33 & 5.26 \\
\hline
\end{tabular}

In our study, Rh positive subjects were predominant with a prevalence of $92.29 \% \mathrm{~s}$, while $\mathrm{Rh}$ negative subjects were only $7.71 \%$ of the study population.

Our results were superimposable on the results of previous studies in Morocco where the D antigen predominated [6, 20, 25].

On the international level our study shows that the prevalence of D antigen (92.29\%) was comparable to that revealed by the Dembele study. AS [26] (92.80\%) in Mali and close to that found by Deba. T [27] in Algeria. In the countries of Asia, two studies had shown a higher prevalence of Ag D than that of our study. The first study was conducted by Liu. J [28] in China, of which $99.71 \%$ had the D antigen. The second study was done in Bangladesh by Talukder. S [29] and revealed a prevalence of 97.4\%. In Europe (Germany [13]), as well as in North America (Canada [20]), the frequency of the RH- phenotype was respectively $17.3 \%$ and $15 \%$. These values were higher than that found in Morocco $(7.71 \%)$. In these parts of the world, there was a greater number of universal $\mathrm{RH}$ donors.

\section{Conclusion}

The phenotypic frequency of blood groups ABO and RHD is not the same in the world; there are variations between countries, as well as between continents. This pushes each country to carry out regular studies in order to know the phenotypic profile of the country and situate it in the world.

\section{References}

[1] Debra J-B, and Connie M-W. Other Blood Group Systems, Collections, and Series. Transfusion Medicine and Hemostasis, 2019.

[2] Kabemba. BH et al. Frequency and Early Neonatal Mortality Related to Anomalies of Birth Weight and Gestational Age in Rural Areas: A Case of the General Reference Hospital of Lubao (Lomami Province, Democratic Republic of Congo). OALib Journal, Volume 4, e3433, 2017. 
[3] Storry JR, Olsson ML. The ABO blood group system revisited: a review and update. Immunohematology. 25 (2): 48-59, 2009.

[4] Khalloufi. A, Taki Imrani. Z, Chegri. M. Etude de la prévalence des groups sanguins ABO, RH et Kell: A propos de 3589 dons de sang dans une région du centre du Maroc, service de transfusion sanguine. Hôpital militaire My Ismail de Meknès, p 2-3, 2017.

[5] Eddoum. K. La prévalence des phénotypes des systèmes ABO, RH et KEL1 chez la population marocaine. Université Mohamed V, Rabat, Thèse ${ }^{\circ} 1,2016$.

[6] Zahid et al. PHENOTYPIC AND ALLELIC DISTRIBUTION OF ABO AND Rh-D BLOOD GROUPS IN BLOOD TRANSFUSION CENTER OF AVICENNA MILITARY HOSPITAL, MARRAKECH, MOROCCO International Journal of Medicine\& Health Research Volume 2, n ${ }^{\circ}, 2016$.

[7] Benahadi et al. Distribution of ABO and Rhesus D Blood Antigens in Morocco. Journal of Biological Anthropology, Vol $6, \mathrm{n}^{\circ} 1,2013$.

[8] Mechali et al. LES GROUPES SANGUINS ABO ET Rh DES HARAT1N DU MAROC. Bulletins et Mémoires de la Société d'anthropologie de Paris, $\mathrm{X}^{\circ}$ Série. Tome 8 fascicule 3-4, $\mathrm{p}$. 196-204, 1957.

[9] El AKERMI. I. Groupes sanguins érythrocytaires chez les donneurs de sang. Thèse Pharmacie, Rabat n ${ }^{\circ} 0,1993$.

[10] Said. N et al. Polymorphisme ABO dans une population de donneurs de sang tunisiens. Transfusion clinique et biologique, $n^{\circ} 10$, p. 331-334, 2003.

[11] BENNAKA. L. Qualification biologique des dons de sang. Etude rétrospective réalisée au centre de transfusion sanguine militaire de Rabat ${ }^{\circ} 122$, p. 62-80, 2004.

[12] Bukasa. H et al. Frequency of Erythrocyte Phenotypes in Blood Group Systems ABO and Rhesus at Moba, Province of Tanganyika, Democratic Republic of Congo. Library Journal, p. 5-8, 2017.

[13] Irem. ZYS et al. ABO and Rh Blood Group Distribution in Istanbul Province. Istanbul Med Journal, n ${ }^{\circ} 6$, p. 98-100, 2015.

[14] Willy A. F et al. Frequencies of the Blood Groups ABO, Rhesus, D Category VI, Kell, and of Clinically Relevant High-Frequency Antigens in South-Western Germany. Onsther transfusions med, $n^{\circ} .22$, p. 285-290, 1995.

[15] Henri-V. Vallois, Paulette Marquer. La répartition en France des groupes sanguins ABO. Bulletins et mémoires de la société d'anthropologie de Paris, $\mathrm{XI}^{\circ}$ Série. Tome 6 fascicule 1, p. 1-200, 1964.

[16] Deba. T. Etude du génotype du système $\mathrm{ABO}$ dans la population de l'Ouest de l'Algérie. Université d'Oran, 17 janvier 2017.

[17] DULAT. $\mathrm{C}$ et al. REPARTITION ETHNIQUE DES GROUPES SANGUINS EN COTE D'IVOIRE. Institut National de Santé Publique - BP V 47 - Abidjan. 36 (11). 1989.
[18] Alia. E et al. Gene frequencies of $\mathrm{ABO}$ and rhesus blood groups in Sabians (Mandaeans), Iraq. J. Baghdad for Science, vol11, n², p. 1035-1042, 2014.

[19] Parul. G et al. Prevalance of ABO and Rhesus Blood Groups in Blood Donors: A Study from a Tertiary Care Teaching Hospital of Kumaon Region of Uttarakhand. Journal of Clinical and Diagnostic Research. Dec, Vol 8, n¹2. 2014.

[20] Adrián. CR et al. Blood Groups Distribution and Gene Diversity of the $\mathrm{ABO}$ and $\mathrm{Rh}$ (D) Loci in the Mexican Population. Hindawi, Bio Med Research International, 2018.

[21] Tlamçani. Z. Les fréquences phénotypiques et génotypiques des systèmes $\mathrm{ABO}$, Rh et KELL dans la population marocaine. Thèse, $\mathrm{n}^{\circ} 34$. p. 36-40, 2012. Kandil et al. Polymorphisme des groupes sanguins (ABO, RH, MNSs et Duffy), chez la population Berbère de Souss (Maroc): Etude comparative avec des populations méditeraniennes. Faculté des science, département de Biologie, El jadida, Janvier 2005.

[22] Loua. A et al. Fréquence des groupes sanguins ABO et rhésus $\mathrm{D}$ dans la population guinéenne. Transfusion Clinique et Biologique $\mathrm{n}^{\circ} 14$, p. 435-439, 2007.

[23] Traoré. O. Phénotype érythrocytaires dans les systèmes de groupes sanguins immunogènes chez les donneurs de sang de Bamako. Université de Bamako. Faculté de Médecine de Pharmacie et D'Odonto-Stomatologie, 2002.

[24] Ivanov V. P et al. Phenotypic frequencies of ABO, Rhesus and MN erythrocyte antigen systems, their gene pool and comparative study of the inhabitants of central Kazakhstan. Genetika, vol 13, nº, p. 1462-1466, 1977.

[25] Lemu. G et al. High rhesus (RHD) negative frequency and ethnic-group based $\mathrm{ABO}$ blood group distribution in Ethiopia. BMC Res Notes n¹0, p. 330, 2017.

[26] Aboulhjoul Idrissi. F. Répartition des groupes ABO et Rhésus au Maroc: étude d'un échantillon de 60000 donneurs de sang. Thèse Médecine, Rabat, ${ }^{\circ} 588,1984$.

[27] DEMBELE A. S. Etude statistique des groupes ABO et Rhésus dans la population malienne enquête préliminaire. Thèse Pharmacie, n5, 1983.

[28] Chiaroni. J. Terminologie numérique des antigènes de groupes sanguins érythrocytaires. Etablissement de transfusion sanguine Alpes-Provence, n 5: 366-71, 1998.

[29] Liu. J et al. Distribution of ABO/RH blood groups and their association with hepatitis $\mathrm{B}$ virus infection in 3.8 milion Chinese adults: a population-based cross-sectional study. Department of Epidemiology and Biostatistics, School of Public Health, Peking University; vol 25, n4 , p. 401-411, Apr 2018.

[30] Talukder S, Das R. Distribution of ABO and Rh blood groups among blood donors of Dinajpur district of Bengladesh Dinajpur Med ColJ n³, p. 55-58, 2010. 